\title{
THE CREATIVE INTERACTION OF BELARUSIAN AND UKRAINIAN CULTURAL LEADERS AT THE AGE OF NATIONAL REVIVAL
}

\section{Hrytsenko H. Z.}

\section{INTRODUCTION}

The peculiarity of inter-Slavonic relations at that time consisted in the political position of the Slavonic peoples, deprived of statehood, gave rise to the idea of Slavonic reciprocity. The Slavonic idea branched off into many variants, but in all its manifestations was utopian: the historical conditions of the existence of each Slavonic people had always been stronger than that idea. However, it influenced the nature of inter-Slavonic cultural ties significantly. The culture that expressed a higher degree of national consciousness, the bearers of this culture generated patriotic sentiments in the neighbors, intensified the processes associated with the formation of national cultures. These interdependent processes were extremely intense and were at the heart of a peculiar phenomenon of Slavonic national revival.

Therefore, it is important to explore Belarusian-Ukrainian relations in the field of education and science of the second half of the XIXth - the beginning of XXth centuries. After all, an important area of cultural contact was education, which was combined with scientific researches, stimulated the interest of local scholars, mainly in the fields of history, literature, folklore, and language.

The creative interaction of Belarusian and Ukrainian cultural figures brought a significant result, which was constantly enriched. The process of education of many representatives of Belarusian culture on the territory of Ukraine was of great importance. Thus, in Belarus in the nineteenth and early twentieth centuries the number of higher education institutions did not meet the needs of the population. The Belarusian artists who studied in Ukraine not only received serious training but also worked in Ukraine, and subsequently initiated the organization of local art education.

The interaction of scientists was clearly manifested in the field of humanities - history, ethnography, folklore and linguistics, great attention was paid to the life, oral folk art of Ukrainians and Belarusians. Belarusian scientists were interested in the works of their Ukrainian colleagues and reviewed their scientific publications in the periodicals. Ukrainians, in their turn, used Belarusian materials and introduced them to scientific use. 
For scientific and cultural interactions between Belarusians and Ukrainians, the publications in which Ukrainian and Belarusian materials stood side by side were of great importance. All this contributed to a deeper knowledge of the two Slavonic peoples, their pressing national problems.

The contacts of Belarusian scientists with Ukrainians created great opportunities for searching and introducing various source materials to the scientific circulation, facilitated the preparation of summarizing works, especially in the Slavonic sphere, made it possible to expand book-sharing, influenced the development of scientific research, etc.

The importance of the study of the topic is reinforced by the formation of a modern system of Belarusian-Ukrainian international relations, the rapprochement of their cultures, which is of great socio-political importance. The absence of generalizations or special works in Belarus and Ukraine, as well as in other countries that would cover most aspects of bilateral cultural relations, reinforces the relevance of the study of the topic outlined. Therefore, the comprehensive research and creative use of the accumulated experience of cooperation and exchange of cultural values will contribute to the enrichment of modern science.

\section{Educational relationships}

According to the census in 1897, the literate population on Belarusian lands was only $25.7 \%$ of the total population. In addition, according to the census, a considerable part of Ukrainians lived on the territory of Belarus. In particular, in Grodno province, Ukrainians made up $22.6 \%$ of the total population, including Kobryn county $-79.6 \%$, Beresteiskyi $-64.4 \%$, and Bielskyi $-39.1 \%$.

Thus, in the second half of the nineteenth century a well-known Belarusian writer, one of the founders of new Belarusian literature, Frantisek Bogushevych (1840 - 1900) studied in Ukraine. An active participant of the Polish uprising of 1863, avoiding repression, he secretly moved to Chernihiv region, where he had been living in Nizhyn, Chernihiv, Konotop for 15 years. On May 29, 1865 F. Bogushevych became a student of Bezborodko Law Lyceum (in 1875 it was renamed into Nizhyn Historical and Philological Institute).

In 1868, F. Bogushevych graduated from the Lyceum as a 12th grade official and got a job in Chernihiv. On November 26 of the same year, he wrote to the Chernihiv vice-governor: "Until December 1, I am on the service in the local administration" $"$. He was appointed an ordinary clerical

\footnotetext{
${ }^{1}$ Народное образование и культура в БССР: Статистический сборник. - М., 1989. - С. 325-326.

${ }^{2}$ Державний архів Чернігівської області. - Ф. 140. - Оп. 1. - Спр. 141. - Арк. 46.
} 
officer, and therefore filed a note of appointment of the rank of provincial secretary, according to his education. This request was granted and F. Bogushevych was transferred to the Chernihiv Chamber of Criminal and Civil Court, appointing a candidate for the post of judicial investigator. $\mathrm{He}$ was recently appointed Acting Investigator of the First Precinct of Borzenskyi District. He was a conscious defender of the interests of Ukrainian peasants.

During 1874 and until 1883 F. Bogushevych served in the judicial bodies of Konotop. The young lawyer, in his practice with many people, always tried to protect their interests. The Ukrainian historian O. Lazarevskyi, the writer P. Kulish, the military writer and theorist M. Dragomyrov lived there. So the investigator F. Bogushevych had the opportunity to communicate with, to align himself. Fifteen years later he returned to his hometown Vilno ${ }^{3}$.

In 1881-1885 the student's life of Yukhim Karskyi (1860-1931), a native of Hrodno, began in Nizhyn. The son of a village clergyman, he graduated from the Minsk Seminary and, in pursuit of higher education, chose Nizhyn Historical and Philological Institute. At the Slavonic-Russian Department, under the supervision of professor R. Brandt, his journey into science began. The first student scientific work "The peculiarities of spelling and language of Suprasl manuscript" was highly appreciated, as was reported in the collection "The News of Nizhyn Bezborodko Historical and Philological Institute" ". Yu. Karskyi informed about the successful defense of his master's thesis at St. Vladimir's University in the letter to the ethnographer P. Shein (1893). "I was received in a friendly way in Kiev, probably because I met many of them at the congress in Vilno, in particular, Antonovych, Vladymyrov ... My dispute went well",5.

Yu. Karskyi was a researcher in Slovonic languages, ethnographer, folklorist, language historian, founder of Belarusian linguistics and literary studies. He is the author of over a thousand scientific papers, reviews, notes.

The well-known Belarusian historian, public figure Mytrofan DovnarZapolskyi (1867-1934) studied at the educational institutions of Kyiv. In 1885, when he studied at the First Kiev High School, he made his debut as a writer. Kyiv life only contributed to the development of the chosen direction and the formation of independence. His small notes on the life of

\footnotetext{
${ }^{3}$ Ильин А. Франтишек Богушевич и Конотопщина // Нёман. - 2000. - № 3. - С. 247-250.

4 Извлечение из протоколов Конференции Института за $1883 / 84$ учебный годъ // Известия историко-филологического института князя Безбородка в Нежине 1883 - 1884. - М. - К., 1885. - Т. 9. C. $126-129$.

${ }^{5}$ Карский А. Академик Карский. Страницы книги // Нёман. - 2011. - № 8. - С. 153.
} 
Kiev were printed in the newspapers "Zorya" (Kyiv) and "Vylenskyi Vesnik".

In February 1888, at the apartment of M. Dovnar-Zapolskyi, a high school inspector found the forbidden to distribute by tsarist government literature, namely the works of M. Drahomanov, M. Kostomarov's letter to A. Herzen, the poem of T. Shevchenko "Maria". This was the reason for his expulsion from the gymnasium two months before the final exams ${ }^{6}$.

The document on the completion of high school education was obtained the following year by M. Dovnar-Zapolskyi: during April - June 1889 he had been taking the exams in 10 subjects at the Fourth Kiev Gymnasium and received a certificate of maturity. His knowledge was assessed as "satisfactory" in 8 subjects, he had not passed the exam in German and received "good" in history".

The following year, he entered St. Vladimir's University, the Department of History and Philology, was studied by the renowned Ukrainian historian V. Antonovych, on the recommendation of which a young scientist was left at the university to prepare for the professorial title. In 1891 M. Dovnar-Zapolskyi published works on historical subjects. One of them concerned the history of Kryvychi and Dregovychi until the end of the XIth century ${ }^{8}$. The second work covered the history of the Grand Duchy of Lithuania and was already directly related to his master's work ${ }^{9}$.

Many immigrants from the territory of modern Belorussia sought spiritual education at Kyiv Theological Academy (KTA), which was considered a prestigious educational institution, and remained in Ukraine while continuing pastoral service. These include the famous historian, teacher, doctor of History, Professor Ivan Malyshevskyi (1828-1897). In 1870-1874 the famous historian Stepan Golubev was a student of KTA. It was I. Malyshevsky that interested him in the history of Church in Ukraine. The course of history of Church by Professor I. Malyshevskyi included general provisions on science and its sources and a systematic review of material from the time of the first Metropolitan Michail to the time of Catherine $\mathrm{II}^{10}$.

\footnotetext{
${ }^{6}$ Купченко В. Маловідомі сторінки біографії М. В. Довнар-Запольського // Ювілейна сесія до 40-річчя від дня народження М.В. Довнар-Запольського. [Збірник]. - Гомель, 2007. - С. 27-28.

${ }^{7}$ Купченко В. Архивные документы о гимназических годах М.В. Довнар-Запольского // Чацвёртыя Міжнародныя Доўнараўскія чытанні: Рэчыца, 18 - 19 вересня 2003 р. - Гомель, 2004. - С. 25.

8 Довнар-Запольский М.В. Очерк истории кривичской и дреговичской земель до конца ХІ столетия / М. Довнар-Запольский. - К., 1891. - 170 с.

9 Довнар-Запольский М.В. Государственное хазяйство Великого княжества Литовского при Ягеллонах. - К., 1901. - VIII, 807, CXII с.

10 Ульяновський B.I. Двічі професор: Степан Голубєв в університетському та академічному контекстах. - К., 2007. - С. 34.
} 
It should be noted that it was S. Golubev who responded with respect about I. Malyshevskyi, who remained for him almost the only authority in "real life""

I. Malyshevskyi was a valid and honorary member of many scientific organizations, the author of numerous scientific works and a supporter of Slavonic cultural unity. His life journey ended in Kiev, where he was buried $^{12}$.

In the early twentieth century the well-known Belarusian poet Yanka Zhurba (real name - Ivan Ivashyn, 1881-1964) studied in Ukraine. After graduating from the Polotsk Teacher's Seminary (1902) and several years of work in the primary schools of Vitebsk province, Ya. Zhurba, wishing to obtain higher education, entered Hlukhiv Teacher's Institute in 1906. During his studies he became a member of the Ukrainian illegal group, in which his students studied Ukrainian literature, and also discussed specific political issues. The participation in such unions aroused the feeling of national consciousness not only in Ya. Zhurba, but also in other Belarusian students ${ }^{13}$. Therefore, when the newspaper "Nasha Nyva" appeared in the walls of Hlukhiv Teachers' Institute, Belarusian students immediately created their own, also illegal, Belarusian union. This newspaper emphasized that "education must be inextricably linked with the soul of a Belarusian, it should develop and enrich him, not cripple, and for this it should be based on the national foundation"14. In one of the letters to the newspaper "Nasha Nyva", the poet Ya. Zhurba wrote: "In the case of the national school, we need to learn from our neighbors, Ukrainians, who have been extensively working for the nationalization of the school for a long time. But this work has grown most in recent years. Scientists from different schools, and vice versa, the simple rural Ukrainian people, have long been demanding their national school with requests, petitions, and needs" $"$.

In 1913, Ya. Zhurba entered Higher Commercial Courses in Kharkiv. However, the savings collected during his teaching years ended quickly and, after studying for over a year, the poet returned to a full-time job in Minsk province.

Taking the example of Ukrainians, Belarusian students created their own union, "the Belarusian National Hebra" (a union of students at Hluhiv Teachers' Institute), headed by Ya. Zhurba. The ideas of the union were self-education in the Belarusian spirit and spreading the idea of a national

\footnotetext{
${ }^{11}$ Там само. - С. 38.

12 Голубева Н. Беларусы Украины // Беларускае замежжа. - Мн., 2010. - С. 172-175.

${ }_{13}$ Максім Багдановіч. Энцыклапедыя / [под. рэд. М. В. Труса]. - Мн., 2011. - С. 219.

143 нашого жыцьця // Наша ніва. - 1910. - № 36. - С. 547-548.

15 Журба Я. Лісты з Украйны II. Клапоты аб національнай школе. - С. 211-212.
} 
Belarusian school. In order to achieve this goal, it was planned to support the Belarusian movement for the national school, read lectures on national affairs, seek Belarusianisation of the school and so on ${ }^{16}$.

Another Belarusian cultural figure who studied in Ukraine was a correspondent of the newspaper "Nasha Nyva", a writer and critic Serhyi Poluyan (1890-1910) ${ }^{17}$. He received his higher education at the University of Kiev in 1908. Together with Ya. Zhurba, he published materials on the cultural life of Ukraine in "Nasha Nyva" under the heading "Letters from Ukraine" (the total number 12) ${ }^{18}$. In one of the letters S. Poluyan wrote that "Kyiv can and should become (as long as we do not have higher schools in Belarus where our youth could study without leaving their native land) one of the centers of Belarusian national work"19. "Regarding that fact what our Ukrainian brothers have come to, one begins to believe that Belarusians and our mother tongue will not perish"20. S. Poluyan collaborated in Kyiv with the magazine "Ukrainska Hata" ("Ukrainian House"), around which young writers of the nationalist movement P. Bogatskyi, G. Chuprynka, M. Yevshan, M. Shapoval and others grouped.

The name of a well-known Belarusian bibliographer, literary critic, translator Romuald Zemkevych (1881-1944) is associated with Lviv ${ }^{21}$. During his studies at Lviv Polytechnics in the 1900's, he translated the novels of V. Stefanyk. Subsequently R. Zemkevych came to the city to work in libraries and archives. In 1909-1911 the works of V. Stefanyk "Death", "A Blue Book", "Evening Time", "A Dream" and others were published in "Nasha Nyva". In order to circumvent censorship, the translator R. Zemkevych and the newspaper's editors changed the titles of individual stories. The poet was subscribed to "Nasha Nyva", had close links with its editorial board and, since 1909, was regularly published in it. It is known that R. Zemkevych studied at Kiev Polytechnic Institute for some time. This is evidenced by his letter to an unknown addressee, written on March 21, 1909: "I am a student of Kiev Polytechnics, I work as a mentor in the family of Mykhailo Svyantsitskyi in Kazimirov. In addition to mentoring, I practice Belarusian ethnography here in my free time ..."22.

\footnotetext{
${ }^{16}$ Ільін А., Гарбачык М. Нацыянальнае адраджэньне пачатку XX ст. : беларуска-ўкраінскія повязі // Спадчына. - 2000. - № 2. - С. 50.

17250 асоб з Беларусі у дыялогах культур / [ред.: Т. Л. Пісарэнка, Л. У. Языковіч]. - Мн., 2008. C. $180-181$.

${ }^{18}$ Из истории школы Белорусии и Литвы / [под ред. Смирнова С. И.]. - М., 1964. - С. 124.

19 Журба Я. Лісты з Украйны VII. - С. 229-230.

${ }^{20}$ Полуян С. Лісты з Украйны IX. - С. 493.

${ }^{21}$ Из истории школы Белорусии и Литвы / [под ред. Смирнова С. И.]. - М., 1964. - С. 182.

22 Скрыжалі памяці: 3 творчай спадчыны пісьменнікаў Беларусі, якія загінулі ў гады Другой сусветнай вайны. У 3 кн. Кн. 2 / [уклад., біягр. давед. пра аўт. і камент. А. Бельскага]. - Мн., 2005. C. 396.
} 
Many Belarussians studied in Lviv educational institutions, including the poetess Tzotka, real name - Aloiza Pashkevych (1876-1916).

A. Pashkevych attended classes of the history of ancient Polish language and literature, read by Professor V. Bruhnalskyi for nine semesters, at Lviv University.

However, it is known that the Austrian Ministry of Education allowed A. Pashkevych to become a full-time student of Lviv University and on July 29, 1912, sent a corresponding document to Lviv. As noted by L. Arabai, a researcher of social and cultural activity, scientific work and artistic creativity of Tziotka, her student ID was preserved in one of the Lithuanian archives. In the form of a photograph, she placed this document in her book. It shows that the ID has registration number 4599, dated September 26, 1912, and signed by Professor V. Bruhalskyi ${ }^{23}$.

At this time Tzotka works a lot. She listens to lectures at the university and is also self-educated: she studies Ukrainian, German and Czech. In evenings, she works at the Ossolinskyi Library, studying history, ethnography, folklore of Poland, Ukraine, Belarus, Lithuania.

The permission to enroll as a full-time students came from the ministry on July 29, 1912, and the expected study began. When filling out a special student card in the dean's office, A. Pashkevych always indicated "Belarusian" in the "native language" column. A. Pashkevych studied at the university only for one semester of 1912/1913. After her graduation, she went to visit her native land and, for unknown reasons, never returned to Lviv $^{24}$.

In Belarus in the nineteenth and early twentieth centuries there were no special music and art schools. Therefore, the youth were forced to travel to other lands where there were conservatories and art schools. In particular, such educational institutions were in Ukraine. Since 1865 the art school was in Odessa, in which the Belarusian artist Lev Alperovych (1874-1913) received his professional education. In 1869 M. RayevskaIvanova opened the first art school in Kharkiv, which was later reorganized into a college. In $1875 \mathrm{M}$. Murashko founded Kyiv Art School, where many Belarusian artists studied ${ }^{25}$. In particular, there in 1883 studied the Belarusian artist Yakov Kruger (1869-1940). There his art education received the Belarusian landscape painter Vitold Bialynytskyi-Birulya (1872-1957), who later became a well-known artist and member of the Association of Mobile Exhibitions (1904). His most famous canvases, created in the early twentieth century: "Eternal snows",

\footnotetext{
${ }^{23}$ Арабей Л. Цётка (Алаіза Пашкевіч). - Мн., 1956. - С. 25.

${ }^{24}$ Ільін А., Гарбачык М. Нацыянальнае адраджэньне пачатку XX ст. : беларуска-ўкраінскія повязі // Спадчына. - 2000. - № 2. - С. 52.

${ }^{25}$ Дробаў Л. Н. Беларускія мастакі ХІХ стагодзя. - Мн., 1971. - С. 68.
} 
“A Spring Day", “Autumn", "Spring”. In 1908 he was awarded the title of Academician of $\mathrm{Art}^{26}$.

One of the first who attemped to open an art school in Minsk was V. $\mathrm{Maas}^{27}$, who worked at Odessa Engineering Department and at the same time at Odessa Art School. He took it as the example of the school that Maas decided to organize in Minsk. In order to collect money for the school, in $1891 \mathrm{~V}$. Maas organized the first local art exhibition in Minsk ${ }^{28}$. However, because of the lack of money, the Belarusian artist opened an art carpentry workshop, percentage of the proceeds of it was to be credited to a future institution's fund. After two years of work, the workshop was also closed.

Another attempt of a graduate of Kyiv Art School, Ya. Kruger turned to be more successful, who opened drawing and painting courses in Minsk in 1904, which were later reorganized into a private art school. At the end of the nineteenth century there were other private schools in Belarus, including Ya. Katsenbogen's in Minsk, and Yuri Pen's Painting School (1854-1937) in Vitebsk ${ }^{29}$.

An important field of educational relations was the pedagogical activity of Belarusians in educational institutions of Naddnipryanshchyna (the territory over the Dniper). The activity of M. Dovnar-Zapolskyi in Nestogor-Chronicler Society is evidenced by the statement of the trustee of Kyiv Educational District to the head of the Society dated back to November 8, 1902. "With the proposal to exclude historical lectures from the program of the public course, organized by the society, of Belarusian professor M. Dovnar-Zapolskyi in the period from November 1902 to March 1903"30.

In Kyiv, in 1906 M. Dovnar-Zapolskyi succeeded in establishing a private higher education institution of economics - Kyiv Higher Commercial Courses. M. Dovnar-Zapolskyi became the first rector of this institution and invariably headed it until March $1917^{31}$. Under the leadership of this scientist, Ukrainian scientist P. Klymenko also specialized in the history of the Lithuanian-Russian state ${ }^{32}$.

In 1899, having successfully passed the exams, he entered the classical gymnasium at Bezborodko Institute of History and Philology.

\footnotetext{
${ }^{26}$ Кацер М. Изобразительное искусство Белоруссии. - Мн., 1969. - С. 150.

27 Дробов Л.Н. Живопись Белорусии ХІХ - начала XX веков. - Мн., 1974. - С. 136.

28 Исторические корни дружбы и единения белорусского и украинского народов / [под ред. Кондуфор Ю.Ю.]. - К., 1978. - С. 227.

29 Дробаў Л.Н. Беларускія мастакі ХІХ стагодзя. - Мн., 1971. - С. 68.

30 Національна бібліотека України імені В. І. Вернадського. Інститут рукопису. - Ф. 8. - Оп. 1. Спр. 3097. - 1 арк.

${ }^{31}$ Державний архів міста Києва (далі - ДАК). - Ф. 153. - Оп. 8. - Спр. 809. - Арк 57.

32 ДАК. - Ф. 16. - Оп. 164. - Спр. 2304. - Арк. 6.
} 
Already in 1908, P. Klymenko - a student of the historical department of the Faculty of History and Philology of St. Vladimir University ${ }^{33}$. Historical and Ethnographic Union at the University became a real scientific school in 1911 for P. Klymenko. He came to it with a desire to study economic history. M. Dovnar-Zapolskyi invited his talented student, whose term of tenure to be a professor's fellowship expired in June 1918, to read a course of lectures on Western Russian history at Kiev Archeological Institute.

It is known about the activity of the Belarussian union "A Star", which active figures were the future Belarusian historians Todor Zabello (1896 - 1935) and Lev Akynshevych (1898 - 1980) in Kyiv (1910). They were also students of M. Dovnar-Zapolskyi. All this confirms that Kiev period was the longest and most fruitful in the life of the scientist.

After graduating from the Hluhiv Teachers' Institute (1911), he worked as a teacher in Poltava region for a while and at the same time continued his literary activity a Belarusian poet Ya. Zhurba. This indicates that there were many Belarusians who studied history, culture of their native land and spread their knowledge among Ukrainians.

The next step in the reform of the education system was the opening of women's educational institutions. On May 26, 1869, the regulations on women's gymnasiums and grammar schools in Belorussian Vitebsk and Mogilev provinces were approved ${ }^{34}$.

Many graduates of higher education institutions from the territory of Ukraine worked in Belarusian grammar schols. During the second half of the 1880s - early 1900s, they held prominent positions in Vitebsk and Mogilev Classical Grammar Schools ${ }^{35}$. In particular, at Vitebsk men's and women's classical gymnasiums a teacher Z. Oshpov, candidate of history and philology department of Kharkiv University; I. Nerush and M. Basangin, graduaters of Nizhyn Historical and Philological Institute taught history and geography. Notable figures in Mogilev gymnasium were the teachers of history and geography P. Savych, G. Gortynskyi, V. Lyubarskyi and others. They were the graduaters of Kiev St. Volodymyr University. This indicates that the graduaters of higher education institutions from the territory of Naddnipryanshchyna region facilitated the establishment of the educational process, spreading their knowledge among Belarusians.

\footnotetext{
${ }^{33}$ Там само. - Арк. 5.

${ }^{34}$ Антошко М. Розвиток освіти на Поділлі кінця XIX - першої половини XX століття // Теоретичні питання культури, освіти та виховання : збірник наукових праць. - К., 2008. - Вип. 36. - С. 8.

35 Памятные книжки белорусских губерній [Электронный ресурс] / Национальная библиотека Беларуси. - Мн., 2012.
} 
During 1877-1887 the Ukrainian teachers P. Sander and Ya. Danylov worked in Slutsk Classical Men's Gymnasium. According to the memoirs of Belarusian public figure Napoleon Charnotskyi, who studied in the third grade of the gymnasium, P. Sander and Ya. Danylov held secret meetings with the students, at which they read T. Shevchenko's "Kobzar" and M. Drahomanov's works ${ }^{36}$.

The Belarusian-Ukrainian relations in the field of education were, in fact, quite one-sided, due to the difficult situation in Belarusian schooling (there was no university) and the comparatively better developed system of education in the Ukrainian lands. Many immigrants from Belarus studied at Nizhyn Institute, Lviv, Kharkiv, Kyiv Universities. During their educational and scientific studies Belarusian students and scientists were able to get acquainted with the real life of Ukrainian people, to compare their situation with the situation of Ukrainians. All this gives reason to speak about the solid basis on which the relations in the field of education, science and literature subsequently developed.

\section{Scientific contacts}

Maxim Bogdanovych played a leading role in the development of scientific relations. He was born on December 9, 1891 in Minsk in the family of an ethnographer. He was educated at Nizhnyi Novgorod and Yaroslavl grammar schools (1902-1911) and Yaroslavl Law Lyceum $(1911-1916)^{37}$. As a student of Yaroslavl Lyceum, he joined the union, where he got acquainted with professor B. Kistyakivskiy, a Ukrainian. The union organized meetings, at which the reports on Slavonvic studies were proclaimed, literary works were read, and folk songs were sung ${ }^{38}$. M. Bogdanovych is the author of a number of works on the history and literature of Ukraine, the best of which occupy a leading place in Belarusian science and journalism. In addition, M. Bogdanovych was so good at Ukrainian that some of his works were written in Ukrainian.

M. Bogdanovych' attention to Ukraine, its history, culture at the beginning of the twentieth century is explained by the stateless position of the Ukrainians and Belarusians, their liberation competition. M. Bogdanovych began to deal with the problem of sub-Austrian Ukrainians under the influence of professor B. Kistyakivskyi. It was in his library where the writer found the necessary sources, on the basis of which he wrote his first historical, ethnographic and literary essays. Among them

\footnotetext{
${ }^{36}$ Czarnocki N. Wspomnienia (Nauczyciele Ukraińcy w Slucku) // Biuletyn Polsko-Ukraiński: tygodnik ilustrowany. - Warszawa, 1934. - № 6. - S. 2-3.

${ }^{37}$ Максім Багдановіч. Энцыклапедыя / [под. рэд. М. В. Труса]. - Мн., 2011. - С. 10.

38 Пігуляк М. Максим Богданович і Західна Україна // Радянське літературознавство. - 1964. № 5. - C. 124 .
} 
were "Ukrainian Cossacks", "Galician Rus", "Hungarian Rus", "Red Rus", "Lviv", "Austrian Ukrainians", and literary studies - "The Forgotten Way", "The Images of Galicia in Fiction", etc ${ }^{39}$. He made an attempt to acquaint the broader Belarusian public with different aspects of the historical-ethnographic, folk-poetic and literary life of Ukrainians in Austrian state with the help of these works. In this area, M. Bogdanovych acted as an active spokesman for the Belarusian-Ukrainian cultural union.

Based on specific material, M. Bogdanovych proved that Ukrainians have a full right for self-development, as they created a rich and glorious history, and glorified the heroic past of the Ukrainian people ${ }^{40}$. It should be noted that all articles were written at the beginning of the First World War, when the attention of the Russian public focused on Galicia as a bridgehead. In the condition of social and national oppression of the Slavonic peoples, he was concerned about the struggle for their selfdetermination. He never separated an ethnographic group into a separate nationality, constantly keeping in view the ethno-spiritual integrity of Ukrainianness $^{41}$.

In their turn, Ukrainian writers and literary critics, who spoke warmly about the personality and creativity of this famous Belarusian poet, did not remain in debt. According to the Ukrainian writer M. Dray-Khmara, he is an outstanding master of a word, who "heard all the manifestations of the national and social liberation of the Belarusian people; with extreme love he treated Ukrainian culture in general, spoke publicly in defense of the assaulted Galicia ... was published in our journals, studied our writing, language, wrote about our writers, translated their works, and even tried to write Ukrainian poetry" ${ }^{\prime 2}$. Similar views were expressed by I. Krypiakevych in the research "Belarusians". He stressed that M. Bogdanovych treated Ukrainians with great sympathy ${ }^{43}$.

It should be noted that the name of not only M. Bogdanovych, but also the famous researcher, Belarusian Arseniy Markevych (1855-1942), a native of Brest-Litovsk, is associated with the Crimea. He left the descendants the most complete study of the peninsula. From 1883 his life was connected with the Crimea, Simferopol, where he was not only engaged in teaching, but also carried out extensive research work, studying the ancient monuments of the peninsula. He was the author of the first scientific works devoted to the Crimea: "A trip to Old Crimea"

\footnotetext{
${ }^{39}$ Богданович М. Стратим-Лебідь. Збірник творів: поезія, проза, публіцистика, критика, листи [пер. 3 білорус. та рос. Р. М. Лубківський [та ін.]. - Л., 2002. - С. 191.

40 Богданович М. Угорська Русь. - Скрентон: 3 друкарнї “Народної волї”, 1916. - С. 11.

${ }^{41}$ Максім Багдановіч. Энцыклапедыя. - Мн., 2011. - С. 160.

${ }^{42}$ Національна бібліотека України імені В. І. Вернадського. Інститут рукопису. - Ф. 10. - Оп. 4. Спр. 17307. - Арк. 3.

${ }^{43}$ Крип'якевич І. Білоруси. - Л.: Накладом т-ва “Просвіта”, 1909. - С. 11.
} 
and "To the history of the Bakhchisarai Palace". The book for every Crimean researcher is his work "Taurika: the Experience of the Index of Works about the Crimea" (1894). On the initiative of A. Markevych, Tavriya University was created on the peninsula - the first higher educational institution of the Crimea, to which he handed over his rich library ${ }^{44}$.

The great Ukrainian writer Ivan Franko showed great interest in Belarusian literature. Some information about Ivan Franko's interest in Belarusian issues dates back to the 1880s. This is evident from his correspondence with the famous Polish writer E. Ozheshko ${ }^{45}$. In the letter dated March 20, 1886, Ozheshko asked I. Franko to provide her the information on a number of issues, the first of which was the issue of the territory of Belarus and Ukraine. On answering these questions, in the letter dated March 31, 1886, I. Franko pointed to some literature on Ukrainian studies, primarily on the works of M. Drahomanov. He stressed that "Drahomanov does not refer Belarus to Ukraine, but recognizes the right of Belarusians to independent national development ...". I. Franko, referring to the authority of $\mathrm{M}$. Drahomanov, shared his views on Belarusians as a separate people. Belarussians Kamenyar considered equal to Russians and Ukrainians ${ }^{46}$.

Honorary place was occupied by M. Dovnar-Zapolskyi in the galaxy of Slavists of the turn of the nineteenth - twentieth centuries. The Dnipropetrovsk researcher S. Abrosimova published two letters of M. Dovnar-Zapolskyi to the famous Ukrainian researcher of the history of Zaporizh Cossacks Dmitro Yavornitskyi (1855-1940) ${ }^{47}$. The first, dated 1902, referred to minor archival matters, and the second, dated October 3, 1905, to the 13th Archaeological Congress held the day before in Katerynoslav. M. Dovnar-Zapolskyi reported immediately the release of "The Book for Reading on Russian History" and suggested D. Yavornitskyi to write an article for the 2nd book about Zaporizh Sich and pointed to the main subjects that should be covered.

The number of Ukrainian correspondents of M. Dovnar-Zapolskyi is relatively small, but it includes the most authoritative representatives of Kiev School of History and Philology and Ukrainian Science. Among them are teachers of M. Dovnar Zapolskyi of Kyiv University and scientists -

\footnotetext{
${ }^{44}$ Голубева Н. Беларусы Украины // Беларускае замежжа. - Мн., 2010. - С. 173.

${ }^{45}$ Львівська національна наукова бібліотека України ім. В. Стефаника, відділ рукопис. - Ф. 82. Оп. 1. - Спр. 24. - Арк. 11-14.

${ }^{46}$ Мараш Я. История Белоруссии эпохи феодализма в интерпретиции Ивана Франко // I. Франко і світова культура: матеріали міжнародного симпозіуму. - К., 1990. - Кн. 1. - С. 120-122.

47 Епістолярна спадщина академіка Д.І. Яворницького. Листи вчених до Д. І. Яворнищького. Дніпропетровськ, 1998. - Вип. 1. - С. 265-269.
} 
V. Antonovych ${ }^{48}$, V. Ikonnikov ${ }^{49}$, P. Golubovskyi ${ }^{50}$. The correspondence with them is not only a valuable source for reconstruction of facts and events related to the scientific development of M. Dovnar-Zapolskyi, but also transferers the style of relations between teachers and students within Kiev school, as well as between representatives of different generations.

The contacts between M. Dovnar-Zapolskyi and M. Hrushevskyi were much stronger. This is due to various reasons, especially the same sociopolitical views, professional interests, and finally the peculiarities of the life path of both scientists. 18 letters of M. Dovnar-Zapolskyi to M. Hrushevskyi, written from Kiev, have been preserved. The largest in size and the most important are four dated back to 1895 and one 1896. M. Dovnar-Zapolskyi informs M. Hrushevsky about his painstaking work in the archives with the archaeographic publication "The Documents of the Moscow Archives of the Ministry of Justice" and, in particular, with the materials of the revision of Berest district 1566.

Five letters from M. Hrushevskyi to M. Dovnar-Zapolskyi and fifteen letters from M. Dovnar-Zapolskyi to M. Hrushevskyi during the period of cooperation with "Notes of NTS" were published in the collection "The correspondence of M. Dovnar-Zapolskyi with scientists of Ukraine (1893-1908)", was the result of the joint work of Belarusian and Ukrainian researchers ${ }^{51}$.

Among the researchers of this period, the first to mention is Ilarion Svyantsitskyi (1876-1956), a philologist, professor of Lviv University. I. Svyantsitskyi's ancestors came from Belarus, although he was born in Lviv region, he always considered himself a bit Belarusian. Perhaps this is one of the reasons for his continued interest in Belarusian history, language and literature.

During his visit to Belarus (1907), I. Svyantsitskyi personally met with Ya. Kupala and his poetry at the apartment of St. Petersburg professor of Belarusian studies B. Epimakha-Shypila. The following year, a Lviv scholar published a booklet entitled "The Revival of Belarusian Writing"52. It was not only the first work on Belarusian literature published abroad, but also the first in-depth study of Belarusian literature, beginning with the time of F. Skoryna's activity and ending with contemporary writings by I. Svyantsitskyi.

\footnotetext{
${ }^{48}$ Центральний державний історичний архів України, м. Київ (далі - ЦДІАК України). - Ф. 262. ОП. 1. - СПР. 159. - 5 арк.

${ }^{49}$ ЦДІАК. - СПР. 165. - 3 арк.

${ }^{50}$ ЦДІАК. - СПР. 162. - 41 арк.

51 Перапіска М. В. Доўнар-Запольскага з дзеячамі навукі Украіны (1893 - 1908 гг.). - Гомель, 2005. $-170 \mathrm{c}$.

${ }^{52}$ Свєнціцький І. Відродження білоруського письменства. - Л., 1908. - 62 с.
} 
As noted by the literary critic from Drohobych M. Shalata, there were several hundred editions in the library of Belarusian I. Svyantsitskyi ${ }^{53}$.

In the early twentieth century another Lviv scholar, a historian I. Krypiakevych, following I. Svyantsitskyi, began to become interested in Belarus. He has written many studies on the various issues of historical relations between Ukraine and Belarus. In 1909 in the printing house of Shevchenko Scientific Society was published his work "Belarusians",54, which he explored the issues of Ukrainian-Belarusian relations in the past.

The well-known popularizer of Belarusian literature was the famous Slavist V. Shchurat. In 1910 he published the article "Shevchenko Zheligovskyi - Chechot" in the journal "Dilo". In 1913 this text was published in his book "Literary Essays" " This indicates that the author was well acquainted with the Belarusian literary and folklore material.

Lviv scholars and writers have done much to familiarize Ukrainians with the history, culture and literature of the Belarusian people. It is quite reasonable to speak of the place of Lviv as a cultural center in the history of the Belarusian-Ukrainian unity.

The folklorist and ethnographer Volodymyr Hnatyuk (1871-1926) strongly opposed the humiliation of the Belarusian people. The researcher sharply criticized the well-known Belarusian writer-democrat and ethnographer M. Kosych for her writing about amorality of polischyks of Mozyr district and often called Belarusians "Lytvyns" in the writings "Lytvyns - Belarussians of Chernihiv province, their life and songs",56, "On the Belarussian Peasant's Buildings" (1906). The Ukrainian reviewer believes that the claim of M. Kosych is biased, that the folk name of the Belarusians "lytvyn" should not be introduced into scientific use without reservations, because it is mocking, offensive ${ }^{57}$.

V. Hnatyuk not only studied Belarusian folk art according to collections known at that time, but also dealt with its collection. He had close scientific ties with some Belarusian scientists ${ }^{58}$. This is evidenced by at least his letters to Y. Kars'kyi, discovered by M. Yatsenko in the Central State Historical Archives (Lviv) (F. 309, Op. 2, ed. 2274) ${ }^{59}$.

The mutual interest of the two peoples in the cultural life of each other was reflected in the Ukrainian and Belorussian periodicals of the early

\footnotetext{
${ }_{53}^{53}$ Шалата М. Два сонця білоруського письменства // Жовтень. - 1982. - № 11. - С. 98.

${ }^{54}$ Крип’якевич І. Білоруси. - Л.: Накладом т-ва “Просвіта”, 1909. - 16 с.

55 Щурат В. Шевченко - Желіговський - Чечот / Літературні начерки. - Л., 1913. - С. 94-99.

${ }^{56}$ Косич М. Литвины-белорусы Черніговской губернии: их быт и песни // Живая старина. - 1901. № 2. - С. 221-260; № 3-4. - С. 1-88.

57 Гнатюк В. [Рецензія]. М. Н. Косичь. Литвины-белорусы Черніговской губернии: их быт и песни // Записки Наукового товариства ім. Шевченка. - Л., 1903. - Т. 55. - Кн. 5. - С. 42-44.

58 Яценко М. Володимир Гнатюк. - К., 1964. - С. 239-240.

${ }^{59}$ Там само. - C. 242.
} 
twentieth century. The constant interest in the Ukrainian theme was evidenced by "Nasha Nyva" - one of the first Belarusian-language weeklies $^{60}$. During the Shevchenko Anniversaries $(1911,1914)$, a number of literary-critical and non-fiction articles appeared in Belarusian writing that initiated pre-October Shevchenko studies in Belarus.

Therefore, a similar situation with education is also evident in the scientific relations between Ukrainians and Belarusians. In the beginning, the relations in this area were limited to those in the humanities. However, later relations in the scientific field began to take on the character of the interaction presented by the activity in Ukraine of Belarusians M. Bogdanovych, A. Pashkevych and others.

\section{CONCLUSIONS}

Despite the fact that the Belarusian-Ukrainian ties (educational and scientific) were rather "young", nevertheless, thanks to the relations of the two peoples, their cultures were enriched with new topics and images. In addition, the Ukrainian and Belarussian cultures have gained extensive experience in the interconnection process. A deep acquaintance with the spiritual achievements of neighboring peoples stimulated the development of one's own culture, showed what it lacked, kept it from repeating mistakes.

The stay of Belarusians in different educational establishments in Ukraine led to the establishment of personal contacts, which subsequently actively promoted scientific relations, dissemination of knowledge and culture in general.

Belarusian students participated in numerous unions and societies of diverse nature and orientation. In this regard, special attention deserves the creative activity on the territory of Ukraine of A. Pashkevych, M. DovnarZapolskyi, Ya. Zhurba, S. Poluyan, F. Bogushevych. Unlike their predecessors, who were interested in Ukraine and knew about it from the stories of eyewitnesses or from literary sources, these scientists and writers lived and worked for a long time among Ukrainians, knew their way of life, thoughts and aspirations.

Belarussian scientists were interested in the works of their Ukrainian colleagues and Ukrainians, in their turn, followed the achievements of researchers of Belarusian literature. Thus, M. Dovnar-Zapolskyi, Y. Karskyi, E. Romanov, and others wrote about Ukrainian writing, culture, and literature, and reviewed periodicals in various scientific publications, including articles pertaining to Ukraine. M. Drahomanov,

\footnotetext{
${ }^{60}$ Національна бібліотека України імені В. І. Вернадського. Інститут рукопису. - Ф. 274. - Оп. 1. Спр. 203.
} 
O. Potebnia, V. Hnatyuk, considering certain problems of history, philosophy, languages, always used Belarusian materials and introduced them to scientific use.

The bilateral cultural ties of the second half of the nineteenth and early twentieth centuries contributed to the revitalization of social and cultural life on the territory of the Belarussian and Ukrainian lands, the spread of innovative pedagogical thought, the development of scientific research, the setting up of publishing activities, etc.

\section{SUMMARY}

The article explores bilateral Belarusian-Ukrainian cultural, educational and scientific ties within the Russian and Austro-Hungarian monarchies. The basic tendencies of educational and cultural activity of individual persons, the role of their relations for national processes are analyzed. It is traced that pedagogical activity of Belarusians in educational establishments of Ukraine was an important area of educational relations, which explains the establishment of personal contacts. Contacts between scientists led to the expansion of research problems, contributed to the development of national science, especially the humanities. The place of Lviv as a cultural center in the history of the Belarusian-Ukrainian unity is explored.

The bibliographic data on a number of the personalities of Belarusian national-cultural movement were revealed, which made it possible to make significant clarifications to their biography.

\section{REFERENCES}

I. Державний архів Чернігівської області. - Ф. 140. - Оп. 1. Спр. 141. - 75 арк. 7 арк.

II. Державний архів міста Києва. - Ф. 16. - Оп. 164. - Спр. 2304. 57 арк.

III. Державний архів міста Києва. - Ф. 153. - Оп. 8. - Спр. 809. -

IV. Львівська національна наукова бібліотека України ім. В. Стефаника, відділ рукопису. - Ф. 82. - Оп. 1. - Спр. 24. - 14 арк.

V. Національна бібліотека України імені В.I. Вернадського. Інститут рукопису. - Ф. 8. - Оп. 1. - Спр. 3097. - 1 арк.

VI. Національна бібліотека України імені В.I. Вернадського. Інститут рукопису. - Ф. 10. - Оп. 4. - Спр. 17307. - 8 арк.

VII. Національна бібліотека України імені В.I. Вернадського. Інститут рукопису. - Ф. 274. - Оп. 1. - Спр. 203. - 10 арк. 
VIII. Центральний державний історичний архів України, м. Київ. - Ф. 262. - Оп. 1. - Спр. 159. - 5 арк.

IX. Центральний державний історичний архів України, м. Київ. Ф. 262. - Оп. 1. - Спр. 162. - 41 арк.

Х. Центральний державний історичний архів України, м. Київ. Ф. 262. - Оп. 1. - Спр. 165. - 3 арк.

1. Антошко М. Розвиток освіти на Поділлі кінця XIX - першої половини XX століття / Марина Антошко // Теоретичні питання культури, освіти та виховання : збірник наукових праць. - К. : Вид. центр КНЛУ, 2008. - Випуск 36. - С. 5-9.

2. Арабей Л. Цётка (Алаіза Пашкевіч) / Лидия Арабей. - Мн. : Мастацкая літаратура, 1956. - 126 с.

3. Богданович М. Стратим-Лебідь. Збірник творів: поезія, проза, публіцистика, критика, листи / [пер. 3 білорус. та рос. Романа Лубківський [та ін.]. - Л. : В-во Світ, 2002. - 406 с.

4. Богданович М. Угорська Русь / Максим Богданович. Скрентон: 3 друкарнї “Народної волї”, 1916. - 24 с.

5. Гнатюк В. [Рецензія]. М. Н. Косичь. Литвины-белорусы Черніговской губернии: их быт и песни / Володимир Гнатюк // Записки Наукового товариства ім. Шевченка. - Л., 1903. - Т. 55. Кн. 5. - С. 42-44.

6. Голубева Н. Беларусы Украины / Наталья Голубева // Беларускае замежжа. - Мн. : Медисонт, 2010. - С. 172-175.

7. Довнар-Запольский М.В. Очерк истории кривичской и дреговичской земель до конца XI столетия / Митрофан Викторович Довнар-Запольский. - К. : Б. в., 1891. - 170 с.

8. Довнар-Запольский М. В. Государственное хозяйство Великого княжества Литовского при Ягеллонах / Митрофан Викторович Довнар-Запольский. - К. : Б. в., 1901. - VIII, 807, CXII с.

9. Дробаў Л. Н. Беларускія мастакі XIX стагодзя / Леонид Никанорович Дробаў. - Мн. : Беларусь, 1971. - 109 с.

10. Дробов Л. Н. Живопись Белорусии XIX - начала XX веков / Леонид Никанорович Дробов. - Мн. : Высшая школа, 1974. - 334 с.

11. Епістолярна спадщина академіка Д. І. Яворницького. Листи вчених до Д. І. Яворницького. - Дніпропетровськ : Гамалія, 1998. Вип. 1. $-888 \mathrm{c.}$

12. Из истории школы Белорусии и Литвы / [под ред. Смирнова С. И.]. - М.: Просвещение, 1964. - 323 с.

13. Ильин А. Франтишек Богушевич и Конотопщина / Александр Ильин // Нёман. - 2000. - № 3. - С. 247-250. 
14. Извлечение из протоколов Конференции Института за 1883/84 учебный годь // Известия историко-филологического института князя Безбородка в Нежине 1883 - 1884. - М. - К., 1885. T. 9. - C. 126-129.

15.Исторические корни дружбы и единения белорусского и украинского народов / [под ред. Кондуфор Ю.Ю.]. - К. : Научная мысль, 1978. - 235 с.

16. Ільін А., Гарбачык М. Нацыянальнае адраджэньне пачатку XX ст. : беларуска-ўкраінскія повязі / Александр Ільін, Мыкола Гарбачык // Спадчына. - 2000. - № 2. - С. 37-57.

17. Журба Я. Лісты 3 Украйны II. Клапоты аб національнай школе / Янка Журба // Наша ніва. - 1909. - № 15. - С. 211-212.

18. Журба Я. Лісты з Украйны VII / Янка Журба // Наша ніва. 1909. - № 16. - С. 229-230.

19. Журба Я. Лісты з Украйны VIII / Янка Журба // Наша ніва. 1909. - № 33. - С. 480.

20. 3 нашага жыцьця // Наша ніва. - 1910. - № 36. - С. 547-548.

23. Карский А. Академик Карский. Страницы книги / Александр Карский // Нёман. - 2011. - № 8. - С. 152-153.

24. Кацер М. Изобразительное искусство Белорусии. Дооктябрский период / Михаил Кацер. - Мн. : Наука и техника, 1969. - 162 c.

25. Крип'якевич I. Білоруси / Іван Крип'якевич. - Л.: Накладом т-ва "Просвіта", 1909. - 16 с.

26. Косич М. Литвины-белорусы Черніговской губернии: их быт и песни / Марія Косич // Живая старина. - 1901. - № 2. - С. 221-260; № 3-4. - С. 1-88.

27. Купченко В. Архивные документы о гимназических годах М.В. Довнар-Запольского в фондах Государственного архива г. Киева / Віра Купченко // Чацвёртыя Міжнародныя Доўнараўскія чытанні: Рэчыца, 18-19 вересня 2003 р. у двох частках. - Гомель, 2004. - C. 22-27.

28. Купченко В. Маловідомі сторінки біографії М. В. ДовнарЗапольського / Віра Купченко // Ювілейна сесія до 140-річчя від дня народження М. В. Довнар-Запольського. [Збірник]. - Гомель, 2007. C. $17-34$.

29. Максім Багдановіч. Энцыклапедыя / [под. рэд. М.В. Труса]. Мн. : Беларус. Энцыкл. імя П. Броўкі, 2011. - 608 с.

30. Мараш Я. История Белоруссии эпохи феодализма в интерпретиции Ивана Франко / Яков Мараш // I. Франко і світова культура: матеріали міжнародного симпозіуму. - К.: Наукова думка, 1990. - Кн. 1. - C. 120-125. 
31. Народное образование и культура в БССР: Статистический сборник. - М. : Финансы и статистика, 1989. - 432 с.

32. Палуян С. Лісты з Украйны IX / Сергей Палуян // Наша ніва. 1909. - № 34. - С. 492-493.

33. Памятные книжки белорусских губерний [Электронный pecypc] / Национальная библиотека Беларуси. - Мн., 2012.

34. Перапіска М.В. Доўнар-Запольскага з дзеячамі навукі Украіны (1893-1908 гг.). - Гомель : Гомельск. дзярж. ун-т імя Ф. Скарыны, 2005. $-170 \mathrm{c}$.

35. Пігуляк М. Максим Богданович і Західна Україна / Микола Пігуляк // Радянське літературознавство. - 1964. - № 5. - С. 121-124.

36. Свєнціцький I. Відродження білоруського письменства / Іларіон Свєнціцький. - Л. : Наклад автора, 1908. - 62 с.

37. Скрыжалі памяці: 3 творчай спадчыны пісьменнікаў Беларусі, якія загінулі ў гады Другой сусветнай вайны. У 3 кн. Кн. 2 / [уклад., біягр. давед. пра аўт. і камент. А. Бельскага]. - Мн. : Бел. кнігазбор, 2005. $-656 \mathrm{c}$.

38. Czarnocki N. Wspomnienia (Nauczyciele Ukraińcy w Slucku) / N. Czarnocki // Biuletyn Polsko-Ukraiński: tygodnik ilustrowany. Warszawa, 1934. - № 6. - S. 2-3.

39. Ульяновський В. Двічі професор: Степан Голубєв в університетському та академічному контекстах / Василь Ульяновський. - К. : НКПІКЗ, “Фенікс”, 2007. - 360 с.

40. Шалата М. Два сонця білоруського письменства / Михайло Шалата // Жовтень. - 1982. - № 11. - С. 97-99.

42. Щурат В. Шевченко - Желіговський - Чечот / Василь Щурат / Літературні начерки. - Л. : Накладом авт.; 3 друк. Наук. Т-ва ім. Шевченка, 1913. - 105 с.

43. Яценко М. Володимир Гнатюк / Микола Яценко. - К. : Наукова думка, 1964. - 288 с.

44.250 асоб з Беларусі у дыялогах культур / [рэд.: Т. Л. Пісарэнка, Л.У. Языковіч]. - Мн. : Ін-т гісторыі, 2008. - 365 с.

\section{Information about the author: Hrytsenko H. Z.}

Candidate of Historical Sciences, Senior Lecturer at the Department of World History and Special Historical Disciplines, Drohobych Ivan Franko State Pedagogical University 46, Lesya Ukrainka str., Drohobych, Lviv region, 82100, Ukraine 